Article

\title{
Foreign Immigrants in Depopulated Rural Areas: Local Social Services and the Construction of Welcoming Communities
}

\author{
Rosario Sampedro ${ }^{1, *}$ and Luis Camarero ${ }^{2}$ \\ ${ }^{1}$ Department of Sociology and Social Work, University of Valladolid, 40005 Segovia, Spain; \\ E-Mail: mariarosario.sampedro@uva.es \\ 2 Department of Sociology I, National Distance Education University, 28040 Madrid, Spain; E-Mail: Icamarero@poli.uned.es \\ * Corresponding author
}

Submitted: 5 April 2018 | Accepted: 7 August 2018 | Published: 28 September 2018

\begin{abstract}
Many rural areas in Spain suffer an acute problem of depopulation. In recent years the arrival of foreign immigrant workers has contributed to alleviating the situation. The social services in rural areas play a fundamental role in the reception of these new residents, and in attending to their needs. These immigrants find themselves in a very vulnerable situation. Added to the needs of any family group with very limited resources are the terms of being a foreigner in an environment in which the coethnic support networks are very scarce. The capacity of both rural councils and local social services to promote the social integration of the immigrants is very limited due to the lack of resources, and to the difficulties associated with the provision of social services in depopulated rural areas. Through in-depth interviews, carried out in a mountainous depopulated region in northern Spain, we analyse the discourses of mayors, social workers and members of civil organizations. The conclusions suggest that the construction of welcoming communities requires reinforcing the community dimension of social work in rural areas, and from an ecological perspective that enhances social participation and coordination among the social actors. Specifically directed initiatives are needed by means of cooperation among the different levels of government and between public and private actors.
\end{abstract}

\section{Keywords}

depopulation; foreigner; immigrant; migration; rural area; social integration; social services; support; Spain

Issue

This article is part of the issue "Vulnerable and Disadvantaged Groups: On the Margins of the Welfare State?", edited by Inger Lise Skog Hansen and Tone Fløtten (Fafo Institute for Labour and Social Research, Norway).

(C) 2018 by the authors; licensee Cogitatio (Lisbon, Portugal). This article is licensed under a Creative Commons Attribution 4.0 International License (CC BY).

\section{Introduction}

A great number of rural areas in southern Europe have experienced a continual process of ageing and depopulation. In the case of Spain and the Iberian Peninsula this process has especially affected the hinterland and mountainous areas. Nevertheless, in recent decades there has been a change in the migratory balance in the rural hinterland with a growing tendency towards the arrival of new residents. The vast majority of these new residents are foreign immigrants who come to work in agriculture, construction, agribusiness, the care of dependent people, and in other services.
The arrival of these foreign immigrants to rural areas is common to many northern countries (de Lima \& Wright, 2009; Findlay \& McCollum, 2013; Hedberg \& Haandrikman, 2014; Rye, 2014; Trevena, McGhee, \& Heath, 2013) and to southern Europe (Camarero, Sampedro, \& Oliva, 2011; Fonseca, 2008; Kasimis, 2008; Kasimis, Papadoulos, \& Pappas, 2010). A large number of articles published on Mediterranean Europe focus on the role of immigrants in the agrarian job markets, and on the conditions of frequently exploited seasonal workers, especially in intensive agriculture for exportation (Corrado, de Castro \& Perrota, 2017; Gertel \& Sippel, 2014; Hoggart \& Mendoza, 1999). Others, however, have placed empha- 
sis on the effect that these new residents might have on the survival of those rural areas undergoing a strong demographic decline (Bayona \& Gil, 2013; Kasimis, 2008; Pinilla, Ayuda, \& Sáez, 2008).

With regard to the depopulated rural areas there are also articles that concentrate on the experience of life that new residents have in the rural environment, and on their expectations for medium- and long-term permanency (de Lima, Parra, \& Pfeffer, 2012; Flynn \& Kay, 2017; Jentsch, 2009; Morén-Alegret, 2008; Rye, 2014). These studies highlight the multidimensional character of integration. Morén-Alegret (2008) distinguishes three aspects: social integration, systemic integration and habitat integration. Social integration is related to the quality of social relationships and participation in community life, whereas systemic integration refers to access to the job market, to public and private services and to the relationship with institutions; finally habitat integration refers to access to housing, and the appraisal of the environmental surroundings. In the same vein Flynn and Kay (2017) highlight the importance of the emotional and material dimension in integration, and how the sense of material and emotional security plays a key role in the decisions of long-term establishment in rural areas.

Another fundamental aspect is the role of social services in the integration of immigrants (de Lima \& Wright, 2009; Depner \& Teixeira, 2012; Jentsch, de Lima, \& MacDonald, 2007; Sethi, 2013). Together with the education system and the health service, the social services in Spain constitute the third pillar of state social welfare. The aim of the social services is to attend to families and individuals who find themselves in need or at risk of social exclusion, by offering them information, orientation and social resources. They must also work in treating and eliminating the root causes of these situations. The social services serve in a wide variety of social problems: poverty, child protection, mental health, disabilities, domestic violence, racism, drug abuse, assisting the elderly, etc. This is done in conjunction with other services and departments in the local administration. Although the main beneficiaries are the needy and vulnerable, another important dimension is the community work aimed at preventing such situations of marginalisation and social exclusion. This means that the state social service system consists both of personal social services geared towards the particular needs and problems of individuals and families, and social programmes and community development aimed at larger groups and populations. Social work with communities has not received the same attention as other units (individuals, families and groups), with regard to its theoretical construction and/or the systematization of its practice in line with a professional exercise; it is usually linked with direct and individualised attention (Pastor, 2015). As a consequence, social policies have basically been focused on the resolution of the difficult social situations at an individual and family level.

In their analysis of the theory and practice of community social work, Taylor and Roberts (1985a) showed the difficulty of building a single model given the innumerable differences amongst various training schools and practices. Pastor (2013) points out two main theoretical perspectives in relation to social work with communities. The former is based on social systems' theory, and focuses on functional interactions among bureaucracies, organizations and communities, with special attention on different functions of the systems; these are adaptation, goal attainment and integration. The latter is the ecological approach that emphasizes the creation of communication channels, participation and interaction among groups and organizations. Empowerment of individuals, groups and communities becomes a key concept, as the main goal of community social work is to make appropriate use of natural networks and energize communities for a variety of endeavours. In other words, the most important thing is helping recipients to overcome difficulties and make them capable of solving problems on their own (Germain, 1985; Germain \& Gitterman, 1996). Linked to this latter theoretical framework is the necessity to highlight a short-range operating conceptual theoretical framework that facilitates the formation of and endows meaning to specific community intervention. Such frameworks are non-directive theory, i.e., the theory of the motivation, necessities and capacities; sustainable human development or dynamic of groups and conflict as key element of the change (Pastor, 2015).

The ecological approach to community social work is also connected to critical and radical social work that emphasises collective action versus personal attention, and promotes a model of intervention attached to the commitment of the professionals towards the active social movements. In this sense, participation becomes a key dimension in postmodern social work (Howe, 1994), and a variety of models that take into account the role of institutions and recipients/communities in the design and management of social policies are considered (Taylor \& Roberts, 1985b; Rothman, 1995). From a perspective that enhances human development, recipients should be considered as citizens (Clark, 2000). The main objective of institutions and public policies should not be direct intervention, but to stimulate civil organizations and support the participative management of integral projects by means of innovative and creative partnership formulae (Pastor, 2015).

The central aims of this ecological and participatory approach to community social work is the empowerment of groups and territories that are usually excluded from decision-making processes and the promotion of intercultural dialogue and coexistence of groups from different backgrounds, nationalities, ethnic origins or capabilities (Jones \& Truell, 2012; Solomon, 1985). The social work with rural communities involves collective action focused on the participation and the mobilization of the people's local resources. The social fabric, the interactions among people who know each other is something that gives the small community a structure of latent power that can be used as a tool for change and local development (Pastor, 2015). 
Some studies directed at analysing the specificities of social work in the rural sphere indicate how, more than anywhere else, should be made no rigid distinction in practices between personal social services and more community focused intervention (Pugh \& Cheers, 2010, p. xvii). In rural areas, people used to rely only on natural or voluntary networks to cope with the sort of needs that social services deal with, or on the village mayor who was also a neighbour and someone to whom people went to with their problems (Martínez-Brawley, 1991, p. 274). After the consolidation of the public system of social services, local social services became the main institutional gateway to information, orientation and resources. It is the place where immigrants, as vulnerable people, go to solve their personal and social needs.

The integration of immigrants has to do with the attitudes and expectations of both the immigrants and the native population, and the ways in which settlement is conducted. The growing ethnic and cultural diversity that characterises the rural environment represents a challenge to the stereotypical homogeneous and conflictfree vision of the rural communities. Further to this, Pugh (2003) indicated that this growing diversity entails a challenge with regard to the provision of social services in the rural environment, since these communities are not free from the emergence of racism and xenophobia. Social integration goes much further than attending to people with serious social needs. Since both newcomers and the local community must be involved, the dimension of the community work of social services is particularly important. It requires a significant effort in the awareness and training of social workers (Pugh, 2003). We should take into account that immigrants are not only needy people; they frequently suffer the social inequalities linked to the so called 'immigrant condition', a social status that is not necessarily related with legal or administrative status but with the lack of social recognition as full members of the community. As Balibar points out the word 'immigrant' is a catch-all category, combining ethnic and class criteria, into which foreigners are dumped indiscriminately, though not all foreigners and not only foreigners (Balibar, 1991, p. 221).

Some articles jointly analyse the visions of the immigrants and the main local participants involved in creating the conditions for good social integration, mainly local politicians and social workers. With reference to immigrants settling in rural Canada, Sethi $(2013$, p. 88) and Depner and Teixeira (2012, p. 86) indicate that on occasions the very social workers and local politicians are prejudiced against certain ethnic minorities, which are considered to have a lesser ability to integrate. The pressure for integration may end up resolving itself through an assimilation into the dominant culture, in which the immigrants find it very difficult to maintain their own cultural identity (de Lima, 2011, p. 212). Many times they lack compatriots with whom they can maintain their homemaking activities. De Lima (2011, p. 215) also indicates the importance of organising activities that can serve as a bridge between the cultures of the immigrants and the native population.

The aim of this study is to explore the role that local social services and rural councils are playing in the welcoming and settlement of foreign-born immigrants in depopulated rural areas. The article is structured with three key questions: What role are local social services playing in the welcoming and settlement of foreign-born immigrants in depopulated rural areas? What sort of barriers do social services and rural councils find to satisfy the material and emotional needs of immigrants? What lessons can be learnt in relation to the construction of welcoming communities?

Here we present the first results of our qualitative research carried out in Tierras Altas (High Lands), a depopulated mountainous area in northern Spain. In-depth interviews with mayors, social service workers and civil organisations members are analysed in terms of the settling and integration of immigrants in the region. From these statements, we set out the necessity of intensifying the community work carried out by the social services in the rural environment and the coordination of public and private actions in order to advance the development of welcoming communities.

\section{Models and Scenarios for Welfare in Rural Areas}

In Spain the arrival of foreign immigrants has been viewed as a great opportunity to stop the depopulation and relentless decline of many rural areas. Many small municipalities have enacted initiatives to attract new residents, especially young couples with children; the aim is to bring to an end the depopulation, maintain local services and revitalise the social life and economy of their villages. Some non-governmental organisations have also developed programmes for settling foreign immigrants in depopulated rural areas. However, the most direct initiatives for repopulation have undoubtedly been by the councils and local networks (Sáez, Ayuda, \& Pinilla, 2016). These initiatives basically consist of offering temporary employment and access to housing to new residents; the jobs and housing generally depend on the councils themselves. Local social service agencies also facilitate the information about and access to the services and benefits to those entitled. Some agrarian trade unions, rural development groups and networks, as well as non-governmental organisations that work with immigrants have acted as intermediaries between municipalities that seek new residents and those immigrants who are prepared to establish themselves in a rural environment.

However, the scarce human and material resources available for small municipalities to develop social welfare policies and tackle the comprehensive treatment of immigration means that such initiatives are far from a complete success. This difficulty is very much related to the nature of the state system of social welfare in Spain. The system in its general features corresponds to a con- 
servative welfare regime, which is characterised by its segmentation of status and familism, following the typology developed by Esping-Andersen (1999, pp. 81-83). With these welfare systems, commonplace in continental Europe, access to social resources largely depend on professional status and on the steady employment of the male bread-winner. They are systems where the family has a central role in the distribution of care, and in the last instance the responsibility for the welfare of family members. This familism is especially acute in southern European Mediterranean countries. Immigrants are in a vulnerable situation because they are often very precariously incorporated into the job market, and have much weaker family support and coethnic networks than the local population does.

In Spain, the responsibility for social welfare, including education, health and social services, falls on the autonomous regions; these are regions that have wide ranging political and administrative autonomy and constitute the second tier of state administration. The seventeen autonomous regions that make up the state are in turn divided into fifty-two provinces and nearly eight thousand municipalities. These constitute the local administration, be they councils -municipal governments-or provincial governments - called in Spanish 'diputaciones'.

The territorial organisation and planning of the social services is the responsibility of the autonomous regions, as is the provision of specialized social services. The municipalities are responsible for providing primary care services. As a general rule, the provincial governments manage the social services for municipalities with less than 20,000 inhabitants, although, in order to make use of their legal competences, some autonomous regions have established in this type of municipalities different forms of organising social services (Martínez-Brawley, 1991).

Districts for provision of social services are established especially in rural areas, and include a large number of municipalities sharing the same team of professionals. These are generally located in the municipality with the highest population, although schedules of attention are provided in the rest of them. The provision of social services in rural areas is very problematic, and scarce human and economic resources are available to the small municipalities. Consequently, they are always dependent on financing from the provincial and autonomous governments. One important element in the provision of social services in Spain is the growing role of diverse private foundations and non-governmental organizations (Red Cross, Cáritas, Intermon Oxfam, Amnesty International, and so on) in the development of programmes directed at populations at risk of social exclusion. The NGOs organise and manage these programmes in collaboration with the town councils.

The 2008 economic recession, and especially the policy of austerity imposed by the rightwing national government since 2011, have meant severe cuts in social costs; this has directly affected social services. For example, between 2010 and 2012 cuts in local social services were around $19 \%$. Most affected were the payment transfers to families and civil organizations, with a reduction of $32.4 \%$ between 2010 and 2013, followed by personnel with a reduction of $11.6 \%$ for the same period (Ramírez et al., 2014). The consequences were a loss of some 10,000 jobs in the local state sector during those three years. The technical and human resources of the NGOs, which to a large extent depend on state and regional financing, have also suffered huge cuts due to the economic recession and the imposition of austere policies.

A recent report on good practice for social and work integration of immigrants in rural Spain demonstrates the leading role of the social services in the municipal activity in this area (OIM, 2018). It highlights that the initiatives are highly focused on attending to families and people with severe social needs (with activities like child-care support, vocational training for unemployed, and remedial classes for children at school), and are carried out in cooperation with NGOs. The most common activities organized to promote the integration and social participation in a wider perspective are intercultural coexistence workshops, where the immigrant and local populations have the opportunity to know about and share diverse cultural activities, such as music, gastronomy, handicrafts, etc. There are also language courses for immigrants whose mother tongue is not Spanish, although this is subject to the presence of financing from other levels of local and regional administration. It is very significant to realise that the only programmes and services specifically dedicated to integration of the immigrant population from a comprehensive perspective are reported in the past; this as they have disappeared due social expenditure cuts brought about by the 2008 recession (OIM, 2018, pp. 12,17). These programmes and services were generally promoted by voluntary federations of municipalities (called 'mancomunidades'), and provided a team of professionals specialised in intercultural mediation and worked in close coordination with the local social services and other local agencies. These services developed a project that went far beyond attending to the most pressing needs of the immigrant population. As examples we could mention research on the characteristics and needs of immigrants, promotion of immigrant associations, diversity training for local employers and civil servants, local radio broadcasts that detail experiences of immigrants to the area, and so on. They worked on their participation and integration in the community on an equal footing, and the creation of a continuous intercultural dialogue between the immigrant and local populations. These programmes and services have been eliminated by the cuts.

If the economic recession has affected the capacity of small municipalities to attend to the needs of the immigrant population, then it has also affected the profile of these populations. The profile of the immigrant population is more family-based than in the early years of immigrant arrival in rural areas, when this population was mainly composed of single men or women (Sampedro \& 
Camarero, 2016). The immigrants who had achieved a more established work situation stood up to the worst years of the recession, and they brought over their families from abroad. Immigrant population is now mainly composed of young couples with children. As such, we may assume that their needs are no longer limited to obtaining a remunerated job, the acquisition of basic linguistic skills, or obtaining permanent residency; they rather have to do with the availability of adequate housing, access to good health and education services, finding a balance between work and family life, and the possibility of bringing over dependent family members from their countries of origin. Their expectations also change in the way that the educational and employment future of their children becomes fundamental. As a wide range of studies indicate, the major challenge for small municipalities that do not wish to be mere stopovers on the way to cities is to take account of these needs and expectations and turn immigrants in all senses into a part of the community.

\section{Fieldwork Context and Methods}

Our research has been carried out in the autonomous region of Castile and León, located in the northern Spanish hinterland. Its settlements are very rural, as $94 \%$ of its towns have fewer than 2,000 residents. Almost $26 \%$ of the rural population lives in these small municipalities, and for decades the region has suffered from a process of depopulation. The population density of the rural municipalities is extremely low, the level of ageing in the rural population is high, and there is an acute demographic gender imbalance, with a significant absence of women.

Three different areas within the autonomous region were selected, and thirty in-depth interviews were carried out, ten in each area. Those asked were immigrants, mayors, social service workers, members of civil organizations, and other key informants.

A qualitative design was selected since it allowed participants to describe their views and experiences in their own words and to raise issues that were important to them. Key interviewees were recruited through contacts developed by the researchers. Immigrants were contacted with the assistance of social services workers, trade unions, rural development agencies, and other civic organizations. All interviews were tape-recorded, transcribed and analysed by topic. Researchers asked the immigrants a series of open-ended questions about settlement experiences, access to service providers, challenges they face in accessing employment, housing and local services, strategies used to cope with barriers they encountered in setting in the area, quality of life, and plans for future moves. Key interviewees were invited to express their views about the needs and expectations of immigrants, how they contribute to the repopulation and survival of the rural areas, and the capacity of local institutions to promote the integration of immigrants in the long-term. The interview method enabled participants to express their views in the location and at the time that suited them.

Along these lines we essentially refer to Tierras Altas, the least populated area of the three chosen. It is situated in a mountainous area in the autonomous region's extreme northeast. The area is made up of nineteen municipalities, and has a total population of 1,600 inhabitants. The head village has 600 inhabitants, a quarter of whom are foreigners, in particular from Bulgaria, Morocco and Ecuador. The village is $42 \mathrm{~km}$ away from the capital of the province, the city of Soria, which has 39,000 inhabitants. The mayors of the two biggest villages in Tierras Altas have been exceptionally active in their attempts to attract new residents to their municipalities. They have been able to count on the cooperation of CEPAIM, a national NGO that works to help migrants and refugees. Since 2002, CEPAIM has developed a project entitled "Nuevos Senderos" (New Paths) with a specific methodology to put rural municipalities seeking new residents in contact with immigrant families who are prepared to start a new life in a rural environment; it accompanies and follows up the sociolaboural integration of the programme's beneficiaries (Fundación CEPAIM, 2009). The project receives state and European Union funding and support.

In Tierras Altas the mayors of the two main villages and a social worker were interviewed, as were six immigrants (three men and three women) from Eastern Europe, Latin America and Morocco. In the provincial capital we interviewed staff members from CEPAIM, as well as staff members of an information centre for immigrant workers run by one of the major national trade unions. The fieldwork was carried out in June 2017.

\section{The Perspective of the Social and Institutional Agents: Local Voluntary Work versus the Challenge of Integration}

In this section we analyse the statements from key interviewees (the mayors of the two main villages in the area, a social worker, member of the local social services department, and a staff member of CEPAIM), in order to describe what their perceptions of the needs of the immigrants are, the role of the councils and local social services, and what problems and challenges are discernible in this area.

The councils and local social services play a fundamental role in the reception of the immigrant population in depopulated rural areas. Cooperation and a strong relationship can be found between mayors and social workers. Local social services depend on the provincial government ('diputación'); as in many other rural regions, the area of coverage includes a large number of municipalities. The social worker that was interviewed describes the social services, whose headquarters are in the head village, as the gateway for immigrants to the community. The social workers give basic guidance and infor- 
mation regarding administrative procedures and social resources; they provide support when dealing with the higher echelons of administration, and even go beyond by offering support in difficult personal situations:

They already know I am here, and that I am a resource for them; they know it. For example, upon arrival at the welcoming, sometimes they come without anything and with debts; it's because they have debts due to cost of the journey. We support them economically, if it is possible. Sometimes in recessions, when they lose their jobs, we support them with emergency social benefits or we apply for the Guaranteed Minimum Income for them. Other times they ask for help to fill out some documents. They tell us, "Please, can you help me fill in this document? I don't know what it is. I don't know what it says". Other times we help them when they want to bring over their families. We help them to write the letter of invitation, so that a mother, father, sibling, aunt or uncle can come for three months. Even sometimes if they have a family problem in their own country, they come to get some advice. They tell us, "Well, this is happening to me". Their requests are of every kind. (Social Worker)

The social workers feel very limited by the lack of support from the higher levels of administration when carrying out activities they consider to be essential for integration; for example, Spanish courses for foreigners. In this context they try to fill a void and find themselves inventing activities that will not satisfy the administrative criteria of the backing financial administrative bodies:

We haven't got a school for adults; a school where they can learn Spanish. We were aware that we weren't teachers, and that we didn't know how to teach. Then, what we did was above all conversation. We spoke about things. We talked to them a lot about the rights and obligations of immigrants. This way we got them to speak Spanish. This last year, after a lot of work and after going many times to the Education Council to explain that we really needed a teacher of Spanish, we got a teacher. Yes, we've got a teacher of Spanish. (Social Worker)

If we have done things, it is because we invented them; this is because we invented everything. We have not received many resources or much help from other departments. (Social Worker)

The acquisition of linguistic skills is more difficult for female immigrants, due to their reduced insertion in the job market, or their lack of continuity within it. As such the absence of these courses especially affects them:

The men have fewer problems to speak the language compared to the women, because they get around more. Sometimes the women, with childcare and the house, don't have so many opportunities to learn it. (CEPAIM staff member)

On the other hand, a good knowledge of Spanish is also a fundamental requisite for acquiring something essential for life in rural areas-a driving licence. The quality of life in the small municipalities is directly related to mobility and a driving licence is something expensive and difficult to obtain for the immigrant population:

You can live easily in a city without a driving licence, but in a village it is extremely difficult to move if you cannot drive. For immigrants the biggest problem to get a driving licence is money, but language is also a problem. If they don't speak Spanish, it is very difficult to pass the exam to get a driving licence. (CEPAIM staff member)

The mayors are strategically important since they have a key role in the provision of two basic elements for the settling and subsequent establishment of the immigrant population: employment and housing. The jobs offered by the councils themselves may be of two types. In the first case, they can offer temporary work in the construction and the maintenance of local infrastructures or with the provision of certain local services. Secondly, they can grant permission to run certain premises; e.g., canteens and hostels that are owned by the municipality. The mayors mediate between other administrative bodies or private businesses to find employment for the new residents:

Mayors provide employment for immigrants in different local services; they offer them to work some hours cleaning or doing other tasks. If at a given moment the immigrant families find themselves at a very low point of activity or have more needs, then the mayors are going to try to find additional jobs for them; they are going to try to get in touch with other local employers and get something for them. (CEPAIM staff member)

With respect to housing, they have a dual role. Firstly, they operate as developers for the municipal housing, which is rented out at discounted prices. Secondly, and from the perspective of the resident population, they act as mediators, as in general locals are very reluctant to rent their empty properties to either nationals or foreigners:

We have many mayors who have said, "We have various unoccupied houses, and I am battling with the population, or rather with the owners, so that they are rented out". (CEPAIM staff member)

I wish five hundred immigrants would come. I would confront the village. I would ask everyone who has an unoccupied house to rent it out. (Mayor A)

Like the social workers, the mayors show a sense of being abandoned by the higher echelons of administration. 
Some employment initiatives are cut short due to the lack of economic support from other administrative bodies of because of legal and bureaucratic obstacles imposed from above. Certain basic services that would establish the population, especially families with school age children, are shut:

I need to double the surface of the nursery and to carry out new construction work. And do you know what help they offered to me? Nothing! (Mayor A)

Immigrants' toddlers aged one, two or three constitute way over $50 \%$ of the nursery. The nursery is very important, if you want to offer a good quality of life for these families. If you don't offer a woman the possibility of a good service or school where she can leave her children, this woman leaves. (Mayor A)

Something that is particularly hard for the families is not having secondary education in the locality. This obliges the children from age twelve to commute daily to the provincial capital or to stay there all week, only being able to return home at weekends:

The mothers...are already saying to their husbands, "Well, there are cheap flats in Soria", and they leave. Do you understand me? (Mayor A)

It also hurts that the neighbours do not provide support. One mayor interviewed referred his attempts to keep the sole baker's shop open by bringing a family of Romanians who were prepared to run the business. The former owners had already retired and were unable to understand the importance of this agreement for the village:

Finally, the owners withdrew, and do you know why? It was because deep down it annoyed them that they were Romanians; furthermore, it annoyed them that probably they were able to run the business better than them. (Mayor A)

The role of mayors as providers of employment and housing places the immigrant population in a situation of great dependence, and conversely, puts the mayors in a complicated situation. Since resources are scarce, they must face demands that may set the local residents against the immigrant population; and the same is also true for different national groups of immigrants:

If the mayors make an offer of employment, they always make the same comment: "If I bring a family of immigrants, and I see someone who is unemployed or whatever, there is going to be a conflict, isn't there?" (CEPAIM staff member)

The relationships between the local population and immigrants are perceived as good, although there are conflicting statements. As studies carried out in other contexts indicate (Pugh, 2003), in small villages the immigrants are "people" rather than members of a group. "My experience is that in a small village the person is more important than the group, isn't it?" (Social Worker), although the statements also give a sign that reticence exists with regard to the access to social resources by immigrants:

It's not really a conflict, but there are some problems. For example, there are some problems with grants, benefits and with the housing. There are problems with the benefits; for example, with the subject of food banks. The local population say, "Why are immigrants given help, when they aren't going to work?" Well then, sometimes, we have to explain it to them. (Social Worker)

Immigrants are still perceived as "foreigners" and, as such, as people with fewer rights than the locals, which is a potential source for racism and xenophobia. Thus, one key area for mayors is to manage potential sources of conflict (if they arise) so that they do not go any further.

It is necessary to draw attention, as indicated in earlier studies (Depner \& Teixeira, 2012; Sethi, 2013), to the traces of racism that appear in the very discourse of the mayors and social worker despite the recognition that the villages need the immigrants. On the one hand, on occasions the statements hint that the foreign immigrants are perceived as the lesser evil. This compared to the ideal that new settlers would be nationals able to invest and create employment for themselves in the villages:

You can be sure that if it weren't for immigrants, this village would disappear. It would be necessary to go to Soria to look for workers. They are the drivers of development here. (Mayor A)

The village is dying, it is dying. What can you do? Look for people! Then, out of one hundred, four or five good ones came, but they came because they didn't have anything else. The worst from each house came. Now it's a bit better. (Mayor B)

There is a lack of understanding of the fears and prejudices that the immigrants feel at being self-employed and a negative view of the use of social benefits:

Sometimes the offers of employment that appear within the rural environment are for self-employment. If you speak to the families about self-employment they automatically think that there is a lot of risk, and that a lot of paperwork is needed. They daren't take that step towards self-employment, even if they don't have to make an investment. (CEPAIM staff member)

On one occasion I said to them that we had work and they refused. They wouldn't become self-employed because then they might have lost the benefits. (Mayor B) 
The Muslim immigrants are perceived as more closed. Their religious customs are seen as a source of problems and as a sign of fanaticism.

We had a local party, and we roasted chicken for Muslim people. After roasting all the chicken, then they said that it wasn't killed facing Mecca, or it didn't have its throat slit facing Mecca. Bah, go to hell! (Mayor B)

Certainly, there is a sense of frustration that comes from bad experiences. After receiving the help and support of the councils, some people don't feel happy in the villages and leave. One mayor dreams of the possibility of obliging the new residents to stay at least five years.

Sometimes, especially with the Moroccans and Ecuadorians, I have thought of making a contract with them, but I have never accomplished this. I don't know if it's legal or not. Also, it could be that these people promise that they will stay at least for five years in the village. Now, you know, one day they are coming, another day they are leaving. Damn it! There is no formality whatsoever. There is no sense of establishing roots. (Mayor B)

Integration is on occasions also unconsciously associated with assimilation. An integrated immigrant is one who doesn't appear to be an immigrant:

He comes from Morocco. He has always worked here, and he is absolutely and totally integrated. He uses a Spanish translation of his name, and he is the area's champion "guiñote" player [a local card game]. I would like to say that, for example, at burials he goes to the funeral mass. Among his group of friends there are no Moroccans. (Social Worker)

\section{Conclusions: The Community Dimension of the Social Services and the Construction of Welcoming Communities in Rural Areas}

The local councils and social services play a key role in attending to the material and emotional needs of the immigrants who are settled in the depopulated rural areas. Although local social services depend on provincial government, a strong relationship can be found between mayors and social workers. Further to the information, orientation and attention to the most urgent needs, the social services provide the attention and support that in the urban settings can be afforded by the coethnic networks and immigrant associations.

Both the mayors and the social service workers function as mediators between the immigrants and the local population, with the aim of providing work or housing and to avoid racist or discriminatory attitudes. This is important since, although the local community is aware of the importance that immigrants have in the survival of the villages, on occasions they are still perceived as com- petitors in terms of social or employment benefits, and in general they are not inclined to provide employment or residential opportunities.

There is the impression that the attention paid to the immigrant population is carried out spontaneously and voluntarily. It is a reactive problem-centred approach to immigration issues more than a proactive integration approach. There are no services or resources specifically aimed at accompanying and facilitating the process of establishment, nor are there clearly defined strategies directed at achieving full social integration. The lack of resources and insufficient support by the other higher up administrative bodies is an important factor, as is the complete lack of an adequate protocol surrounding the process of establishment. However, some NGOs have already developed such sets of rules. The experience of these NGOs should be taken into account, and a more permanent collaboration between them and the local institutions should be established. There also appears to be insufficient awareness with regard to intercultural issues, and, for that matter, to skills for intercultural mediation. In fact, certain racist attitudes can be perceived from the very mayors and social workers. This may, for example, be by maintaining negative stereotypes towards certain groups of immigrants or subconsciously identifying integration with cultural assimilation. These factors may be considered important obstacles for attaining integration and long-term settlement of immigrants.

From the statements made by those interviewed, the need to reinforce the community work aimed at increasing social participation and networking between social actors is detached from the social services. Working on the intercultural coexistence and dialogue is needed to improve the opportunities within the grasp of the immigrant population. Strong support from the higher up administrative bodies is needed to sustain the economic and social initiatives that facilitate long-term settling down, both for the immigrant population and for the local residents. Increasingly, the immigrant population presents a stable and family profile, and as such has clear needs and demands with regard to educational services and the balance of work versus family life.

Giving an answer to the needs of a group with such different characteristics definitely represents a challenge for social services in the rural environment. Using the cases of Depner and Teixeira (2012) and Sethi (2013) from Canada as a reference, one adequate policy measure would be the creation of specialized services for comprehensively attending to the immigrant population, with workers adequately trained in intercultural mediation and operating at the local level; this would be in close coordination with the social services and other local agencies operating in the welfare system (education, health, housing and employment) and in close cooperation with civic organizations. They would become an efficient instrument in the construction of truly welcoming communities capable of retaining the immigrant community both on a mid- and long-term. 


\section{Acknowledgements}

This study forms part of the Project "Recession and immigration in the rural environment of Castile and León" (CSO2015-67525-R, MINECO/FEDER). This is a research project financed for the period 2015-2018 in the State RDI Programme orientated at the Challenges of Society. The project is incorporated into the IsoRural Network of Excellence (CSO2016-61728-REDT).

\section{Conflict of Interests}

The authors declare no conflict of interests.

\section{References}

Balibar, E. (1991). Racism and crisis. In E. Balibar \& I. Wallerstein (Eds.), Race, nation, class. Ambiguous identities (pp. 217-227). London: Verso.

Bayona, J., \& Gil, F. (2013). Is foreign immigration the solution to rural depopulation? Sociologia Ruralis, 53(1), 26-51.

Camarero, L., Sampedro, R., \& Oliva, J. (2011). Foreigners, neighbours, immigrants: Translocal mobilities in rural areas in Spain. In C. Hedberg \& R. do Carmo (Eds.), Translocal ruralism: Mobility and connectivity in European rural spaces (pp. 143-162). New York, NY: Springer.

Clark, C. L. (2000). Social work ethics: Politics, principles and Practice. Basingstoke: MacMillan.

Corrado, A., de Castro, C., \& Perrota, D. (Eds.). (2017). Migration and agriculture. Mobility and change in the Mediterranean area. London: Routledge.

de Lima, P. (2011). Boundary crossing: Migration, belonging/'un-belonging' in rural Scotland. In C. Hedberg \& R. do Carmo (Eds.), Translocal ruralism: Mobility and connectivity in European rural spaces (pp. 203-217). New York, NY: Springer.

de Lima, P., Parra, P., \& Pfeffer, M. (2012). Conceptualizing contemporary immigrant integration in the rural United States and United Kingdom. In M. Shucksmit et al. (Eds.), Rural transformations and rural policies in the UK and US (pp. 79-99) London: Routledge.

de Lima, P., \& Wright, S. (2009). Welcoming migrants: Migrant labour in rural Scotland. Social Policy and Society, 8(3), 391-404.

Depner, W., \& Teixeira, C. (2012). Welcoming communities? An assessment of community services in attracting and retaining immigrants in the South Okanagan Valley (British Columbia, Canada), with policy recommendations. Journal of Rural Community Development, 7(2), 72-97.

Esping-Andersen, G. (1999). Social foundations of postindustrial economies. New York, NY: Oxford University Press.

Flynn, M., \& Kay, R. (2017). Migrants' experiences of material and emotional security in rural Scotland: implications for longer-term settlement. Journal of Rural
Studies, 52, 56-65.

Findlay, A., \& McCollum, D. (2013). Recruitment and employment regimes: Migrant labour channels in the UK's rural agribusiness sector, from accession to recession. Journal of Rural Studies, 30(1), 10-19.

Fonseca, M. L. (2008). New waves of immigration to small towns and rural areas in Portugal. Population, space and place, 14, 525-535.

Fundación CEPAIM. (2009). Proyecto Nuevos Senderos. Guía metodológica Nuevos Senderos. Integración de familias inmigrantes en zonas rurales despobladas. Madrid: Fundación CEPAIM, FSE, Ministerio de Trabajo e Inmigración.

Germain, C. B. (1985). The place of community work within an ecological approach to social work. In S. H. Taylor \& R. W. Roberts (Eds.), Theory and practice of community social work (pp. 30-59). New York, NY: Columbia University Press.

Germain, C. B., \& Gitterman, A. (1996). The life model of social work practice. Advances in theory \& practice (6th ed.). New York, NY: Columbia University Press.

Gertel, J., \& Sippel, S. (Eds.). (2014). Seasonal workers in Mediterranean agriculture. The social costs of eating fresh. London: Routledge.

Hedberg, C., \& Haandrikman, K. (2014). Repopulation of the Swedish countryside: Globalization by international migration. Journal of Rural Studies, 34, 128-138.

Hoggart, K., \& Mendoza, C. (1999). African immigrant workers in Spanish agriculture. Sociologia Ruralis, 39(4), 538-562.

Howe, D. (1994). Modernity, postmodernity and social work. Review The British Journal of Social Work, 24(5), 513-532.

Jentsch, B. (2009). Migrant integration in rural areas. Evidence from new countries of immigration. International Journal of Multicultural Studies, 9(1), 1-12.

Jentsch, B., de Lima, P., \& MacDonald, B. (2007). Migrant workers in rural Scotland: Going to the middle of nowhere. International Journal on Multicultural Societies, 9(1), 35-53.

Jones, D. N., \& Truell, R. (2012). The global agenda for social work and social development: A place to link together and be effective in a globalized world. International Social Work, 55(4), 454-472.

Kasimis, C. (2008). Survival and expansion. Migrants in Greek rural regions. Population, Space and Place, 14, 511-524.

Kasimis, C., Papadoulos, A. G., \& Pappas, C. (2010). Gaining from rural migrants: Migrant employment strategies and socioeconomic implications for rural labour markets. Sociologia Ruralis, 50(3), 258-276.

Martínez-Brawley, E. (1991). Social services in Spain: The case of rural Catalonia. International Social Work, 34, 265-286.

Morén-Alegret, R. (2008). Ruralphilia and urbophobia versus urbophilia and ruralphobia? Lessons from immigrant integration processes in small towns and ru- 
ral areas in Spain. Population, Space and Place, 14, 537-552.

OIM. (2018). Buenas prácticas para la integración social y laboral de inmigrantes en el ámbito rural en España. Proyecto PEAR 2018. Madrid: Instituto Universitario de Estudios dobre Migraciones. Retrieved from www.imserso.es/InterPresent1/groups/imserso/doc uments/binario/bpintinmig.pdf

Pastor, E. (2013). Metodología y ámbitos del trabajo social comunitario para impulsar cambios sociales sostenibles y autónomos en el complejo universo relacional en España en el siglo XXI. Emancipaçao, 13(1), 143-158.

Pastor, E. (2015). Social work and local community development in the 21st century. Arbor, 191(771), a208. http://dx.doi. org/10.3989/arbor.2015.771n1010

Pinilla, V., Ayuda, M. I., \& Sáez, L. A. (2008). Rural depopulation and the migration turnaround in Mediterranean Western Europe: A case study in Aragon. Journal of Rural and Community Development, 3, 1-22.

Pugh, R. (2003). Considering the countryside: Is there a case for rural social work? British Journal of Social Work, 33, 67-85.

Pugh, R., \& Cheers, B. (2010). Rural social work. An international perspective. Bristol: Policy Press.

Ramírez, J. M., Brezmes Nieto, M. J., Barriga Martín, L. A., García, G., Parreño, A., \& Santos Martí, J. (2014). La Ley de Racionalización y sostenibilidad de la administración local: Un ataque a la democracia local y a los servicios sociales de proximidad. Servicios Sociales y Política Social, 3100(106), 57-79.

Rothman, J. (1995). Approaches to community intervention. In J. Rothman, J. L. Erlich \& J. E. Tropman (Eds.), Strategies of community organization (5th ed.; pp.
26-63). Itasca: F.E.Peacock Publishers.

Rye, J. F. (2014). The Western European countryside from an Eastern European perspective: Case of migrant workers in Norwegian agriculture. European Countries, 4, 327-346.

Sáez, L. A., Ayuda, M. I., \& Pinilla, V. (2016). Pasividad autonómica y activismo local frente a la despoblación en España: El caso de Aragón analizado desde la economía política. Ager. Revista de estudios sobre despoblación y desarrollo rural, 21, 11-41.

Sampedro, R., \& Camarero, L. (2016). Inmigrantes, estrategias familiares y arraigo: Las lecciones de la crisis en las áreas rurales. Migraciones, 40, 3-31.

Sethi, B. (2013). Newcomer resettlement in a globalized world: the role of social workers in building inclusive societies. Critical Social Work, 14(1), 81-100.

Solomon, B. B. (1985). Community social work practice in oppressed minority communities. In S. H. Taylor \& R. W. Roberts (Eds.), Theory and practice of community social work (pp. 217-257). New York, NY: Columbia University Press.

Taylor, S. H., \& Roberts, R. W. (Eds.). (1985a). Theory and practice of community social work. New York, NY. Columbia University Press.

Taylor, S. H., \& Roberts, R. W. (1985b). The fluidity of practice theory: An overview. In S. H. Taylor \& R. W. Roberts (Eds.), Theory and practice of community social work (pp. 217-257). New York, NY: Columbia University Press.

Trevena, P., McGhee, D., \& Heath, S. (2013). Location, location? A critical examination of patterns and determinants of internal mobility amongst post-accession Polish migrants in the UK. Population, Space and Place, 19(6), 671-687.

\section{About the Authors}

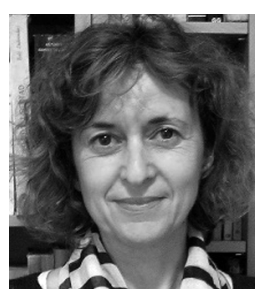

Rosario Sampedro is an Associate Professor of Sociology at the University of Valladolid (Spain). Her research is primarily on rural sociology and gender issues, with a focus on the different dimensions of mobility as a key factor of current rural societies. At present she is involved in research projects focussing on the settlement of foreign immigrants in rural areas in Spain as a way to better understand the underlying conditions for social sustainability and the economic development of rural communities.

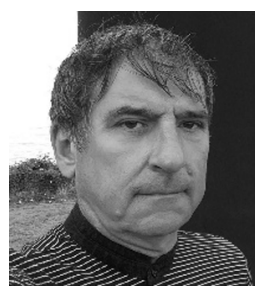

Luis Camarero is a Sociologist and Professor at the Theory, Methodology and Social Change Department, National University of Distance Education (Madrid). He has conducted several research projects on the demographic and socioeconomic transformations of southern European rural areas. He is author of many books and articles focussing on social sustainability in rural areas and on the new social inequalities related both to gender issues and mobility. 